\title{
早田美和 学位論文審査要旨
}

$\begin{array}{ccccc}\text { 主查 } & \text { 難 } & \text { 波 } & \text { 栄 } & \text { 二 } \\ \text { 副主查 } & \text { 入 } & \text { 澤 } & \text { 淑 } & \text { 人 } \\ \text { 同 } & \text { 中 } & \text { 島 } & \text { 健 }\end{array}$

\section{主論文}

Clinical and genetic epidemiological study of 16q22.1-1inked autosomal dominant cerebellar ataxia in Western Japan

（西日本における16q22.1に連鎖する常染色体優性遺伝性小脳失調症の臨床的、遺伝疫学的 研究)

(著者：林美和、足立芳樹、森昌忠、中野俊也、中島健二)

平成19年 Acta Neurologica Scandinavica掲載予定 
学 位 論 文 要 旨

\section{Clinical and genetic epidemiological study of 16q22.1-I inked autosomal dominant cerebellar ataxia in Western Japan}

（西日本における16q22.1に連鎖する常染色体優性遺伝性小脸失調症の臨床的、遺伝 疫学的研究)

脊髄小脳変性症 (SCD) は、臨床的に進行性の平衡機能障害や四肢協調運動障害などの小脳 失調を主徵とし、小脳のみならず、脳幹や大脳基底核、あるいは脊髄などの系にも障害が 及びうる神経変性疾患の総称とされている。これらは更に細かく分類され、常染色体優性 遺伝性春髄小脳失調症 (ADCA) だけでも約30にのぼる病型が知られ、日本においては、春髄 小脳失調症6型（SCA6）の頻度が多いとされている。近年、ADCAの一部に、第16番染色体長 腕に連鎖する常染色体優性遺伝性小脳失調症 (16q22.1-1inked ADCA) があり、これは puratrophin-1遺伝子の翻訳開始地点上流16塩基に一塩基置換 $(\mathrm{C} \rightarrow \mathrm{T})$ がみられることが解 明されている。本研究は、原因未同定であるSCDのうち、16q22.1-1inked ADCAの頻度を明 らかにするために遺伝子スクリーニングを行い、陽性例の臨床的、画像的特徵をまとめた ものである。

\section{方 法}

1998年の鳥取県地域悉皆調査において抽出されたSCD有病者 91 人 (20家系 28 人に家族歴あ り)を対象として、puratrophin-1遺伝子上流多型の有無を検討した。また、1996年から2006 年の間に、鳥取大学医学部附属病院脳神経内科へ遺伝子検査依頼のあった 176 人のSCD患者 のなかで、16q22.1-1inked ADCAが占める割合を検討し、その臨床症状や画像所見について まとめた。

\section{結 果}

鳥取県地域悉皆調査において、SCA6が15人、16q22.1-1inked ADCAが7人であり、それぞ

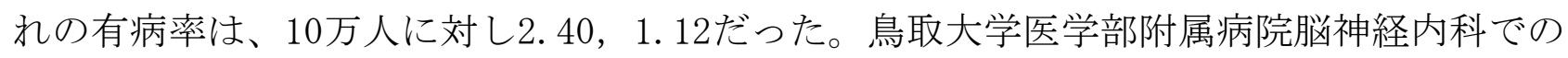
調査では、12人(うち孤発性SCD 26人中2人)が16q22.1-1inked ADCAだった。

臨床的には、16q22.1-1inked ADCAは小脳失調の他にも、錐体路、錐体外路症状、認知症 を示し、また認知症を呈した症例では頭部MRIにてleukoaraiosisを呈する傾向にあった。 


\section{考 察}

日本での16q22.1-1inked ADCAの頻度は、10.5\%〜40\%と多様であるが、本研究では、この 地域のADCA中の約20\%（SCA6の約2/3の頻度）を占めており、SCA6に次いで二番目に多いこ とを明らかにした。また、孤発例のなかにこの病型を見いだしたことは、他の報告ではほ とんど見られず、注目すべき点である。この理由の1つとしては、本症例は比較的発症年齢 が高いため、過去の症例では平均寿命が短く発症前に死亡し、孤発性と誤診されていたこ とが考えられる。

更に16q22.1-1inked ADCAは、SCA6のように純粋小脳失調を呈すると報告されていたが、 本研究では、それ以外にも錐体路症状 (58\%)、錐体外路症状 $(50 \%)$ 、認知症 $(58 \%)$ が頻繁にみ られることが明らかになった。また、認知症を呈した症例では、頭部MRIにて leukoaraiosis(67\%)を呈する傾向がみられ、このことは今までに報告がなく注目される。 一般的に、leukoaraiosisの最も重要な危険因子としては高血圧症が知られているが、 16q22.1-1inked ADCA症例では高血圧の頻度は25\%と低かった。よってこの遺伝子変異は、 小脳変性のみならず脳の血管病変の原因となる可能性が考えられる。

\section{結 論}

16q22.1-1inked ADCAの有病率をはじめて明らかにした。日本のこの地域では、家族性SCD における16q22.1-1inked ADCAの頻度は2番目に多い病型であり、一見孤発性の患者におい ても、puratrophin-1遺伝子の変異を調べる必要を示唆していると考えられる。 